\title{
Identification of the para-nitrophenol catabolic pathway, and characterization of three enzymes involved in the hydroquinone pathway, in pseudomonas sp. 1-7
}

Shuangyu Zhang, Wen Sun, Li Xu, Xiaomei Zheng, Xiaoyu Chu, Jian Tian, Ningfeng Wu ${ }^{*}$ and Yunliu Fan

\begin{abstract}
Background: para-Nitrophenol (PNP), a priority environmental pollutant, is hazardous to humans and animals. However, the information relating to the PNP degradation pathways and their enzymes remain limited.

Results: Pseudomonas sp.1-7 was isolated from methyl parathion (MP)-polluted activated sludge and was shown to degrade PNP. Two different intermediates, hydroquinone ( $\mathrm{HQ}$ ) and 4-nitrocatechol (4-NC) were detected in the catabolism of PNP. This indicated that Pseudomonas sp.1-7 degraded PNP by two different pathways, namely the $\mathrm{HQ}$ pathway, and the hydroxyquinol (BT) pathway (also referred to as the 4-NC pathway). A gene cluster (pdcEDGFCBA) was identified in a $10.6 \mathrm{~kb}$ DNA fragment of a fosmid library, which cluster encoded the following enzymes involved in PNP degradation: PNP 4-monooxygenase (PdcA), p-benzoquinone (BQ) reductase (PdcB), hydroxyquinol (BT) 1,2-dioxygenase (PdcC), maleylacetate (MA) reductase (PdcF), 4-hydroxymuconic semialdehyde (4-HS) dehydrogenase (PdcG), and hydroquinone (HQ) 1,2-dioxygenase (PdcDE). Four genes (pdcDEFG) were expressed in $E$. coli and the purified $p d c D E, p d c G$ and $p d c F$ gene products were shown to convert HQ to 4-HS, 4HS to MA and MA to $\beta$-ketoadipate respectively by in vitro activity assays.

Conclusions: The cloning, sequencing, and characterization of these genes along with the functional PNP degradation studies identified 4-NC, HQ, 4-HS, and MA as intermediates in the degradation pathway of PNP by Pseudomonas sp.1-7. This is the first conclusive report for both 4-NC and HQ- mediated degradation of PNP by one microorganism.
\end{abstract}

Keywords: para-Nitrophenol, Catabolism, Hydroquinone pathway, Hydroxyquinol pathway, Pseudomonas

\section{Background}

para-Nitrophenol (PNP) is a common environmental pollutant owing to its wide application in pharmaceuticals, explosives, dyes and agrochemicals. PNP also accumulates in the soil due to the hydrolysis of organophosphorus insecticides such as parathion or methyl parathion (MP) [1]. Although PNP is less toxic than MP, it is also considered a significant potential toxic contaminant $[2,3]$ and belongs to one of 275 hazardous substances commonly found at Superfund sites $[4,5]$.

\footnotetext{
* Correspondence: wunf@caas.net.cn

Biotechnology Research Institute, Chinese Academy of Agricultural Sciences, 12 Zhongguancun South Street, Haidian District, Beijing 100081, PR China
}

Many PNP-degrading bacteria have been isolated and their PNP degradation pathways studied $[2,6,7]$. In general, there are two alternative oxidative pathways that have been identified based on their distinct intermediates. The hydroquinone (HQ) pathway, in which PNP is degraded via $\mathrm{HQ}$, is the predominant pathway in gramnegative bacteria such as Moraxella sp. [2] and Pseudomonas sp. strain WBC-3 (Figure 1, upper) [3]. The hydroxyquinol (BT) pathway is always used in grampositive bacteria such as Bacillus sphaericus JS905 [7] and Rhodococcus opacus SAO101 [5]. PNP is degraded via $4-\mathrm{NC}$ and $\mathrm{BT}$ in this pathway (Figure 1, lower). However, recently a gram negative organism, Burkholderia sp. strain SJ98, was reported to degrade PNP
() Biomed Central

(c) 2012 Zhang et al; licensee BioMed Central Ltd. This is an Open Access article distributed under the terms of the Creative Commons Attribution License (http://creativecommons.org/licenses/by/2.0), which permits unrestricted use, distribution, and reproduction in any medium, provided the original work is properly cited. 


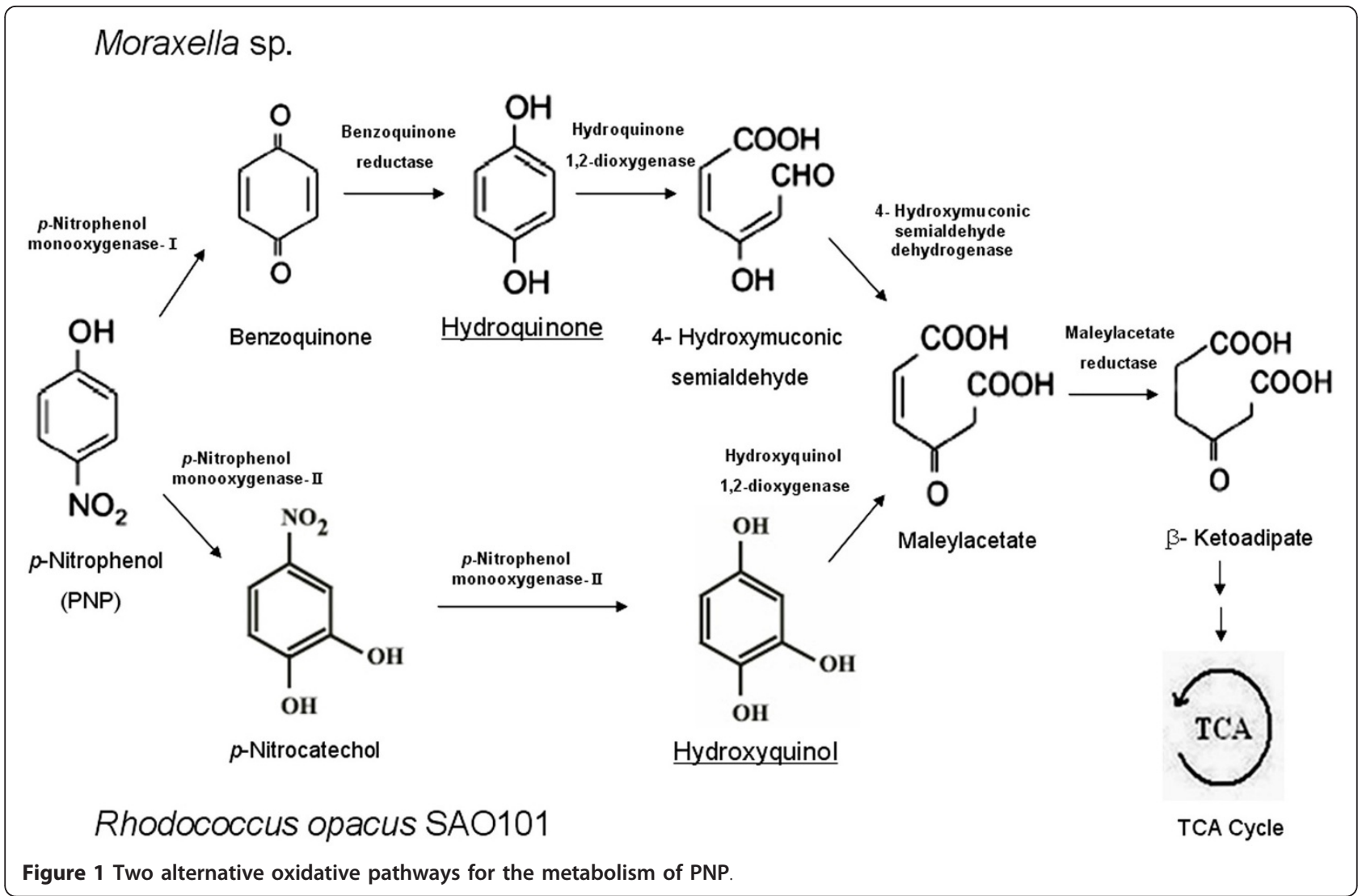

through the BT pathway, with no HQ pathway being detected [8]. In a gram positive organism, Rhodococcus sp. strain PN1, a two component PNP monooxygenase NpsA1A2 was found to catalyze PNP to both HQ and $\mathrm{BT}$ in the presence of ascorbic acid as a reducing reagent. However, no microbial degradation data or results from direct enzyme analyses were provided [9]. We are not aware of any reports of one bacterium being able to degrade PNP utilizing two different pathways.

Although some studies examining PNP degradation have been reported, genetic information related to the PNP degradation pathways remains limited. In the BT pathway, two enzymes were first characterized from Rhodococcus opacus SAO101: one was the two-component PNP monooxygenase $\mathrm{NpcAB}$; the other was the one-component BT 1,2-dioxygenase $\mathrm{NpcC}$. However, the other enzymes involved in this pathway have not been identified [5]. In Arthrobacter sp. strain JS443, another two-component monooxygenase gene NpdA1A2 has been identified [4]. Recently, Chauhan A et al. identified two lower stream genes ( $p n p C D)$ encoding $\mathrm{BT}$ 1,2-dioxygenase and maleylacetate (MA) reductase in this pathway [8]. It is worth mentioning that there are two clusters involved in PNP degradation in the grampositive bacterium Rhodococcus sp. strain PN1. Within these two clusters, two kinds of two-component PNP monooxygenase genes (nphA1A2 and npsA1A2), a regulator protein gene $(n p c R)$ and a BT 1,2-dioxygenase gene $(n p s B)$ have been identified $[9,10]$. For the HQ pathway, the first gene cluster was obtained from $\mathrm{Pseu}$ domonas sp. strain WBC-3, and three enzymes involved in PNP degradation, PNP 4-monooxygenase (PnpA), $p$ benzoquinone $(\mathrm{BQ})$ reductase $(\mathrm{PnpB})$ and $\mathrm{BT}$ 1,2-dioxygenase (PnpG), have been characterized [3,11]. The rest of the genes in this PNP degradation gene cluster have not been identified. Recently, Shen W et al. identified five genes ( $p n p A C C 1 C 2 R)$ in another gram-negative PNP-degrading bacterium, Pseudomonas putida DLL$\mathrm{E} 4$, but the rest of the genes (pnpBDE) in this gene cluster were not identified [12]. To date, all the studies have focused on identifying the upper stream genes in the HQ pathway, while the knowledge of the lower stream pathway genes, especially that of the 4-HS dehydrogenase [13], remains limited.

In this study, a gram-negative bacterium Pseudomonas sp. 1-7, with the ability to degrade both MP and PNP, was isolated from MP-polluted activated sludge. Microbial degradation studies showed that the intermediate products were $\mathrm{HQ}$ and 4-NC, which indicated that both the HQ pathway and BT pathway were utilized in 
Pseudomonas sp. 1-7. Additionally, a $10.6 \mathrm{~Kb}$ gene cluster ( $p d c E D G F C B A)$ was identified from a genomic library. Genes: $p d c D E, p d c F$ and $p d c G$ were chosen to be expressed in Escherichia coli for characterization.

\section{Methods}

\section{Strains, plasmids, and chemicals}

The plasmids and bacterial strains used in this study are listed in Table 1. Pseudomonas sp. 1-7 was grown at $30^{\circ}$ $\mathrm{C}$ in Luria Bertani (LB) medium and Burk mineral medium [14] with $1 \mathrm{mM}$ MP or $0.5 \mathrm{mM}$ PNP as the sole carbon and nitrogen source, respectively. E. coli strains were grown in $\mathrm{LB}$ medium at $37^{\circ} \mathrm{C}$ and were transformed as described [15]. The primer sequences used for PCR are listed in Additional file 1: Table S1. All reagents used in this study were purchased from Sigma Chemical (St. Louis, MO, 113 USA) and Amresco Chemical (Solon, OH 44139 USA).

\section{Isolation of Pseudomonas degrading MP and PNP}

Activated sludge $(0.5 \mathrm{~g})$ collected from a pesticide factory (Tianjin, China) was cultured overnight at $30^{\circ} \mathrm{C}$ in $100 \mathrm{ml}$ liquid Burk medium, before being diluted and spread on solid Burk medium containing 0.1\% (v/v) MP pesticide and incubated at $30^{\circ} \mathrm{C}$. The positive strain able to degrade MP produced a visible hydrolysis halo around the colonies on the plate. Positive colonies were inoculated in liquid Burk medium containing $0.1 \%(\mathrm{v} / \mathrm{v})$ MP pesticide and cultured overnight at $30^{\circ} \mathrm{C}$. MP degradation to PNP was assessed by monitoring whether the medium changed color from colorless to yellow. Further incubation for 2 days was used to test whether this was followed by PNP degradation, confirmed by a subsequent color change from yellow to colorless. Finally, the ability of this bacterium to degrade MP and PNP was confirmed by a second inoculation on a Burk agar plate containing $0.1 \%(\mathrm{v} / \mathrm{v}) \mathrm{MP}[16]$.

\section{Extraction of the intermediates from culture}

After the cultures had reached late log-phase in LB medium supplemented with $0.5 \mathrm{mM}$ PNP, bacteria were harvested and washed in Burk medium by centrifugation. The bacteria were then incubated as concentrated cell suspensions (optical density of 1.5 at $600 \mathrm{~nm}$ ) in Burk medium containing 1.5 mM PNP. Samples were collected at different time points, centrifuged, and aromatic compounds were extracted from the cell-free supernatants as described by Samanta et al [17].

\section{Characterization of intermediate compounds by HPLC and MS}

Identification and quantification of intermediates was performed based on their UV-visible spectra, MS spectra and by chromatographic comparison with standards. The HPLC system consisted of an Agilent 1100 model G1312A binary pump, a model G1330B autosampler and a model G1315B DAD (Agilent Technologies, Inc., Wilmington, DE) equipped with a C18 reversed phase column $(5 \mu \mathrm{m} ; 250 \times 4.6 \mathrm{~mm}$; SunFire) using a column temperature of $30^{\circ} \mathrm{C}$. The mobile phase was $30 \%$ methanol (pH 3.0) at a flow rate of $0.5 \mathrm{ml} \mathrm{min}^{-1}$. PNP, HQ and 4-NC were all detected in the range 220-400 $\mathrm{nm}$. Under these conditions, authentic PNP, HQ, and 4-NC had retention times of 75, 10.5 and 45 min, respectively.

MS spectra of the intermediate compounds were obtained by the following procedure: a mass selective detector (Agilent, 6430, Ion Trap) was equipped with an ESI using a cone voltage of $25 \mathrm{~V}$ and a capillary voltage of $3.5 \mathrm{kV}$ for negative ionization of the analytes (ESImode). The dry nitrogen was heated to $325^{\circ} \mathrm{C}$ and the

Table 1 Bacterial strains and plasmids used in this study

\begin{tabular}{|c|c|c|}
\hline Strains and plasmids & Relevant genotype or characteristic(s) & Reference or source \\
\hline \multicolumn{3}{|l|}{ Pseudomonas sp } \\
\hline Strain 1-7 & methyl parathion and $p$-nitrophenol utilizer, wild type & This study \\
\hline \multicolumn{3}{|l|}{ E.coli } \\
\hline Trans10 & $\mathrm{F}^{-} \Phi 80\left(\right.$ lacZ) M15 lacX74hsdR($\left(\mathrm{r}_{K}^{-} \mathrm{m}_{K}{ }^{+}\right)$recA1398endA1tonA & TransGen \\
\hline BL21(DE3) & $\mathrm{F}^{-}$ompT hsdS (rB- mB-) gal dcm lacY1(DE3) & Novagen \\
\hline \multicolumn{3}{|l|}{ Plasmids } \\
\hline pET30a & $\mathrm{Km}^{\mathrm{r}}$, Expression vector & Novagen \\
\hline pET22b & Ampr, Expression vector & Novagen \\
\hline pET2230 & Ampr, Expression vector & This study \\
\hline pEASY-T3 & Ampr', Cloning vector & TransGen \\
\hline pET30- $p d c F$ & BamHI-Hindlll fragment containing $p d c F$ inserted into pET30a & This study \\
\hline pET30- pdcG & BamHI-Xhol fragment containing pdcG inserted into pET30a & This study \\
\hline pET30- $p d c D$ & BamHI-Xhol fragment containing $p d c D$ inserted into pET30a & This study \\
\hline pET2230- pdcE & BamHI-Xhol fragment containing pdcE inserted into pET2230 & This study \\
\hline
\end{tabular}


drying gas flow was $81 \mathrm{~min}^{-1}$. Data were acquired in the negative scan mode in the range $30-500 \mathrm{Da}$. The mass of each compound was calculated from its peak area.

\section{Construction of a genomic DNA library}

All DNA isolation and cloning procedures were carried out essentially as described by Sambrook et al. [15]. Construction of the fosmid library strictly followed the protocol of the CopyControl ${ }^{\mathrm{TM}}$ HTP Fosmid Library Production Kit of EPI (Epicentre Biotechnologies, Madison, WI, USA).

\section{Cloning of the genes involved in PNP degradation}

The fosmid library was screened for the positive strains that contained the genes involved in PNP degradation using a PCR-based library screening method. The primers (Ps-F and Ps-R) (Additional file 1: Table S1) were designed based on a conserved region which was identified by comparing the amino acid sequences of available BT dioxygenase gene sequences.

\section{Sequence analysis}

The nucleotide sequence of the positive clone was determined by the National Key Facility Open Laboratory of the Chinese Academy of Agricultural Sciences (Beijing, China). The sequences were assembled using the Contig Express program of the Vector NTI suite 7.0 (InforMax, Frederick, MD, USA). Open reading frames (ORFs) in the assembled sequence were analyzed by the ORF finder tool [18], and deduced amino acid sequences were examined by BLASTP in NCBI [19]. The potential signal peptides and hydrolytic domains of the identified genes were predicted using SignalP 3.0 (http://www.cbs.dtu.dk/ services/SignalP). Multiple alignments between protein sequences were performed using ClustalW1.83.

\section{Expression in $E$. coli of genes involved in PNP degradation}

Four genes were selected for expression in E. coli. Genes ( $p d c D E F G$ ) were amplified by PCR from the positive clones, inserted into expression vectors pET30a (Novagen) or pET2230, and transformed into the expression host E. coli BL21 (DE3), respectively. The primers with their restriction sites are shown in Additional file 1: Table S1. The backbone and the multiple cloning sites of pET2230 originated from pET22b and pET30a, respectively. All positive colonies harboring the corresponding gene were confirmed by DNA sequencing. All host cells harboring the recombinant vectors were grown in $\mathrm{LB}$ at $37^{\circ} \mathrm{C}$ to an $\mathrm{OD}_{600}$ of 0.6 and then induced by the addition of IPTG $(0.4 \mathrm{mM}$ final concentration) and incubation at $16^{\circ} \mathrm{C}$ for $16 \mathrm{~h}$ to yield the recombined proteins with fused $\mathrm{His}_{6}$ tags.

\section{Purification of recombinant proteins}

E. coli BL21 (DE3) cells harboring the expression plasmid of interest were harvested by centrifugation and resuspended in $20 \mathrm{mM}$ Tris- $\mathrm{HCl}$ buffer ( $\mathrm{pH} \mathrm{8.0)}$. The crude cell extracts were prepared by sonication [20]. All His-tagged recombined proteins $\left(\mathrm{His}_{6}-\mathrm{PdcF}, \mathrm{His}_{6}-\mathrm{PdcG}\right.$ and $\mathrm{His}_{6}$-PdcDE) were purified from the corresponding E. coli crude cell extract using Ni-nitrilotriacetic acid agarose $\left(\mathrm{Ni}^{2+}-\mathrm{NTA}\right)$ (Qiagen, Valencia, CA, USA) according to the manufacturer's protocol. The purified proteins were characterized by sodium dodecyl sulfatepolyacrylamide gel electrophoresis (SDS-PAGE).

\section{Enzymatic assays}

The enzyme assays are described in the Additional file 1 (Methods of Enzyme Assays). All assays, where applicable, were performed using cell extracts prepared from non-induced BL21 (DE3) cells that harbored the corresponding recombinant vector and from BL21 (DE3) cells that harbored the non-recombinant expression vector as the negative controls.

\section{GenBank accession number}

The nucleotide sequences of the Pseudomonas sp. 1-7 $16 \mathrm{~S}$ rDNA and the PNP degradation gene cluster were deposited in the GenBank database [GenBank FJ821774 and GenBank FJ821777, respectively].

\section{Results}

\section{Isolation of Pseudomonas sp. 1-7}

Strain 1-7, capable of degrading both MP and PNP and collected from a pesticide factory in Tianjin, China, was identified as a Pseudomonas sp. by $16 \mathrm{~S}$ rDNA analysis, which sequence has been deposited in the Agricultural Culture Collection of China (ACCC), with collection number [ACCC 05510] [16]. When Pseudomonas sp. 17 was cultured in Burk medium containing $0.1 \%(\mathrm{v} / \mathrm{v})$ MP pesticide, the color of the culture changed to yellow from colorless, indicating that the MP had been hydrolyzed to PNP. After incubation for a further 2 days, the color reverted to colorless, indicating PNP degradation. Moreover, this strain exhibited the same phenomenon on a culture plate containing $0.1 \%(\mathrm{v} / \mathrm{v}) \mathrm{MP}$ pesticide: generation of a distinct hydrolysis halo, the color of which first turned yellow and then became colorless. Pseudomonas sp. 1-7 was thus able to degrade both MP and PNP.

In former studies, the full-length of methyl parathion hydrolase gene ophc3 from this bacterium was cloned by constructing genomic library. The gene ophc3 was expressed in E. coli and recombinant methyl parathion hydrolase OPHC3 was purified and the enzymatic properties were studied [16]. 


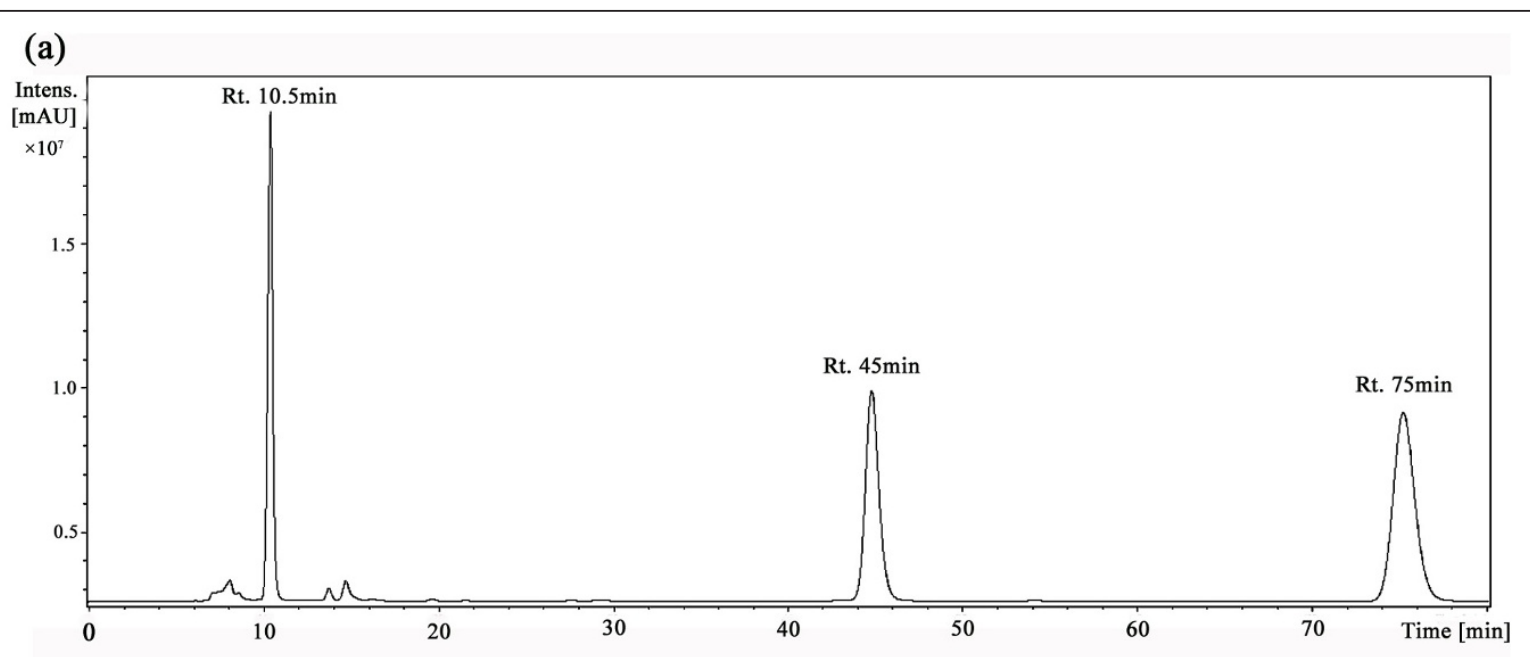

(b)

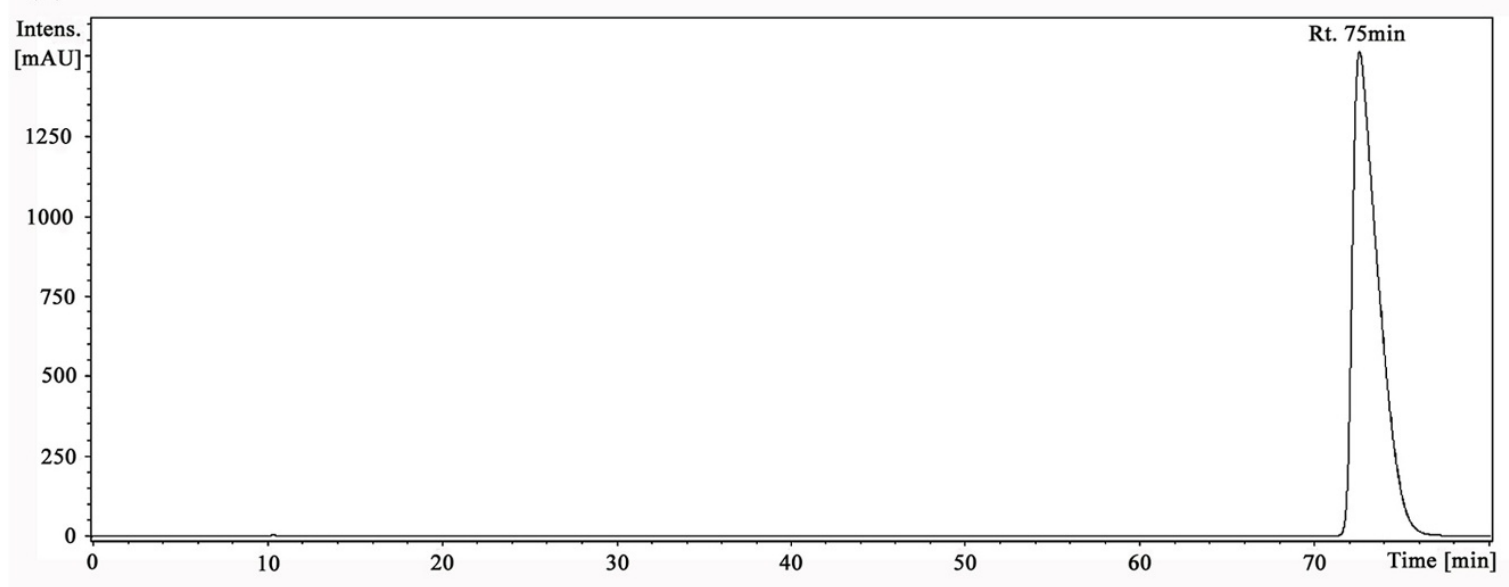

(c)

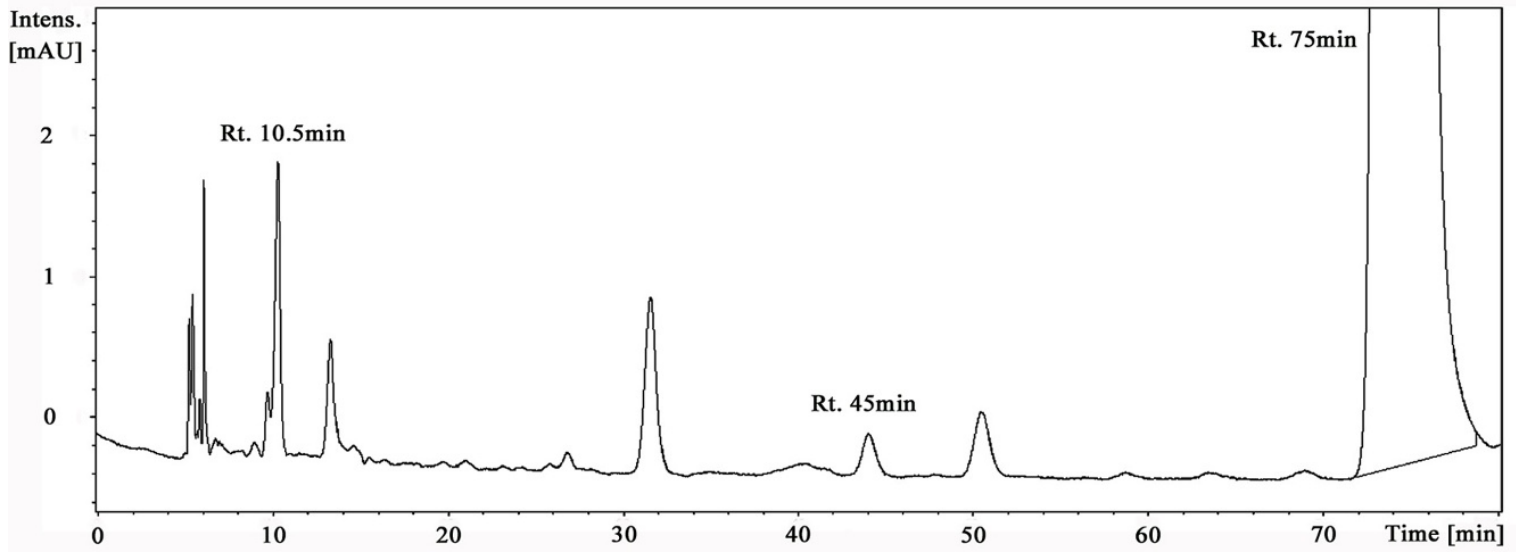

Figure 2 HPLC analyses of supernatants of Preudomonas sp. 1-7 grown on PNP. (a) HPLC chemical standards: authentic PNP, HQ and 4-NC had retention times of 75, 10.5 and 45 min, respectively; HPLC analysis of cell-free supernatants at (b) $0 \mathrm{~h}$ and (c) $3.5 \mathrm{~h}$.

Strain 1-7 degraded PNP utilizing both HQ and BT pathways

To determine how Pseudomonas sp. 1-7 degraded $\mathrm{PNP}$, the reaction intermediates were analyzed by
HPLC. The analyses yielded three distinct peaks with retention times of $10.5 \mathrm{~min}, 45 \mathrm{~min}$, and $75 \mathrm{~min}$ in samples drawn at $0-3.5 \mathrm{~h}$ intervals. These retention times corresponded with those of the standard 

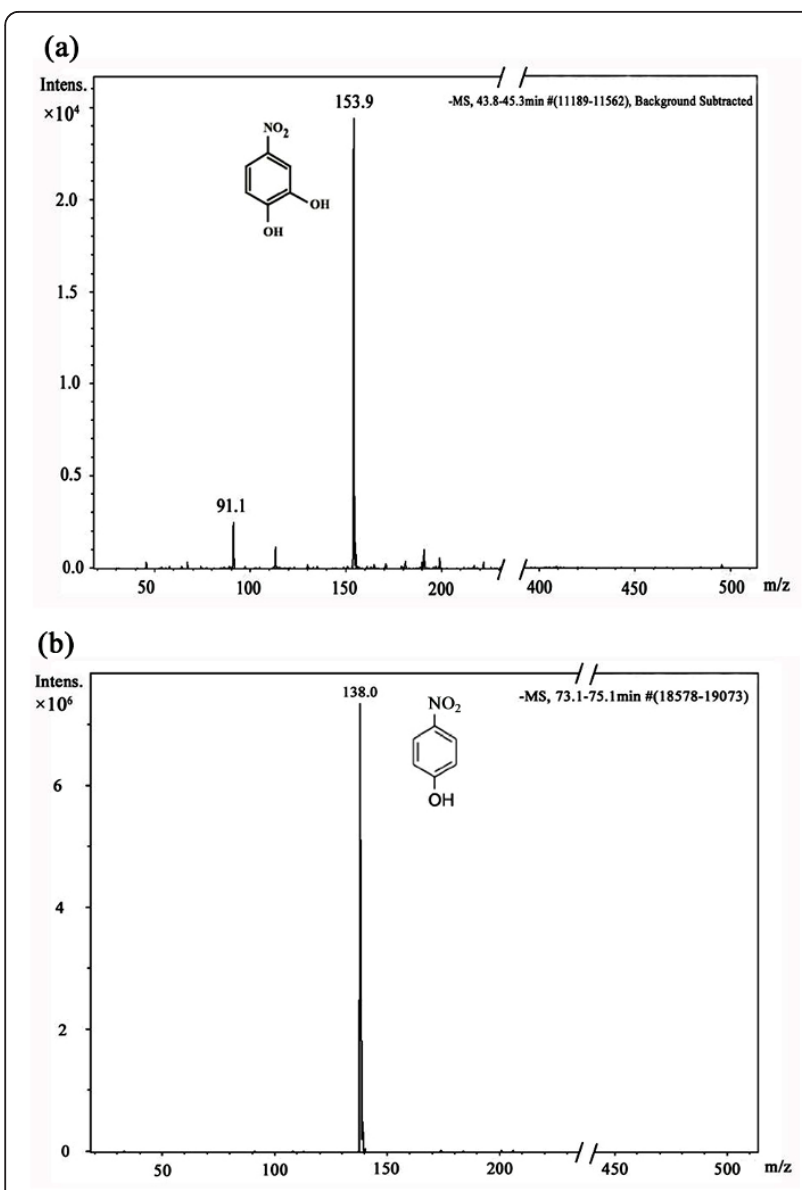

Figure 3 LC-MS analyses of supernatants of Pseudomonas sp. 1-7 grown on PNP. Mass of the intermediates identified in the peaks with retention times of $45 \mathrm{~min}(\mathbf{a})$ and of $75 \mathrm{~min}(\mathbf{b})$ in the sample extracted after $3.5 \mathrm{~h}$.

compounds $\mathrm{HQ}, 4-\mathrm{NC}$ and PNP, respectively (Figure 2 ). In addition, the $220-400 \mathrm{~nm}$ absorption spectra of all the detected peaks corresponded with those of the standard compounds (Additional file 1: Figure S1). The HPLC studies thus confirmed the presence of PNP, 4$\mathrm{NC}$ and $\mathrm{HQ}$ in the culture medium.

The LC-MS analyses of the $3.5 \mathrm{~h}$ HPLC samples showed the two peaks with the retention times of 45 $\mathrm{min}$ and $75 \mathrm{~min}$ as having molecular ion at $\mathrm{m} / \mathrm{z}$ of 153.9 and 138.0, respectively (Figure 3 ). These $m / z$ results

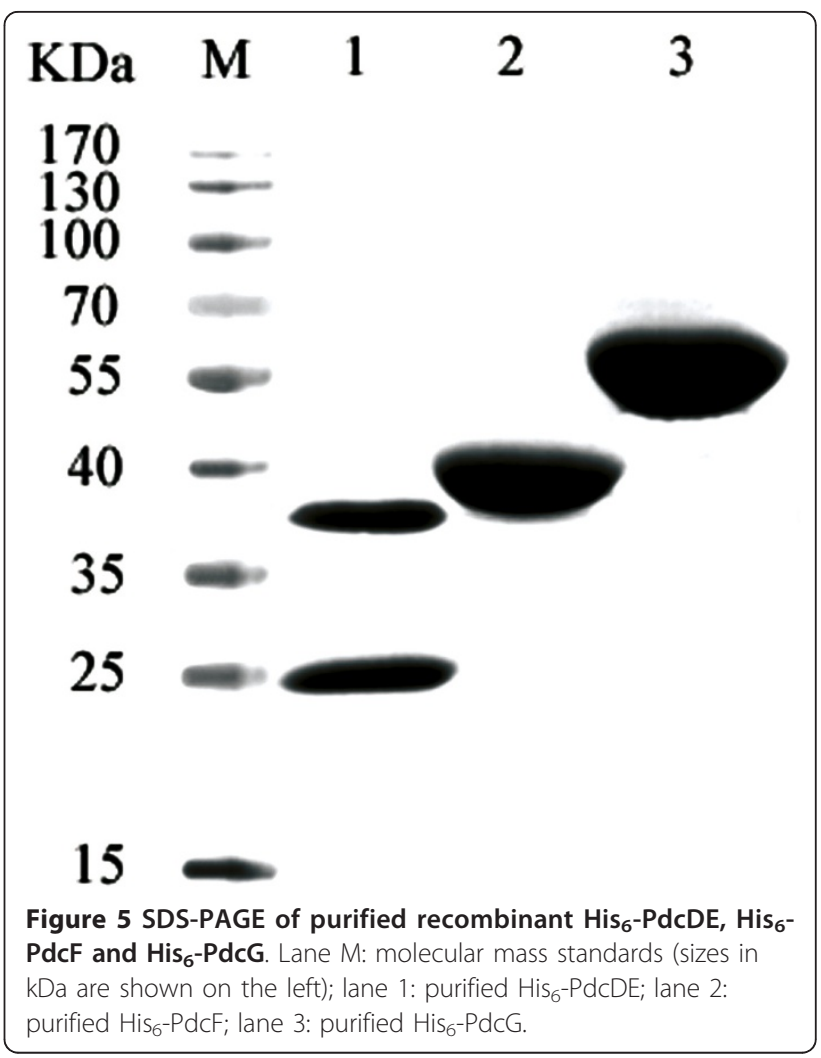

matched the standard $m / z$ of $4-\mathrm{NC}$ and PNP and confirmed the identities of the two peaks as 4-NC and PNP, respectively. However, because the nonpolar HQ molecule could not be detected by LC-MS, we were unable to confirm that the HPLC peak with the retention times of 10.5 min was, in fact, HQ.

Additionally, culture supernatants collected at various time intervals showed a sharp depletion of PNP within $3.5 \mathrm{~h}$, and clearly demonstrated the accumulation of $\mathrm{HQ}$ and 4-NC from $3.5 \mathrm{~h}$ onward. The maximum amount of 4-NC was detected at $3.5 \mathrm{~h}$, and the maximum amount of $\mathrm{HQ}$ at $30 \mathrm{~min}$ (Additional file 1: Figure S2).

These results identified both HQ and 4-NC as intermediates in the degradation of PNP by strain 1-7. Being intermediates in the HQ and BT pathways, respectively, both of the two PNP degradation pathways are therefore utilized in PNP mineralization by strain 1-7.

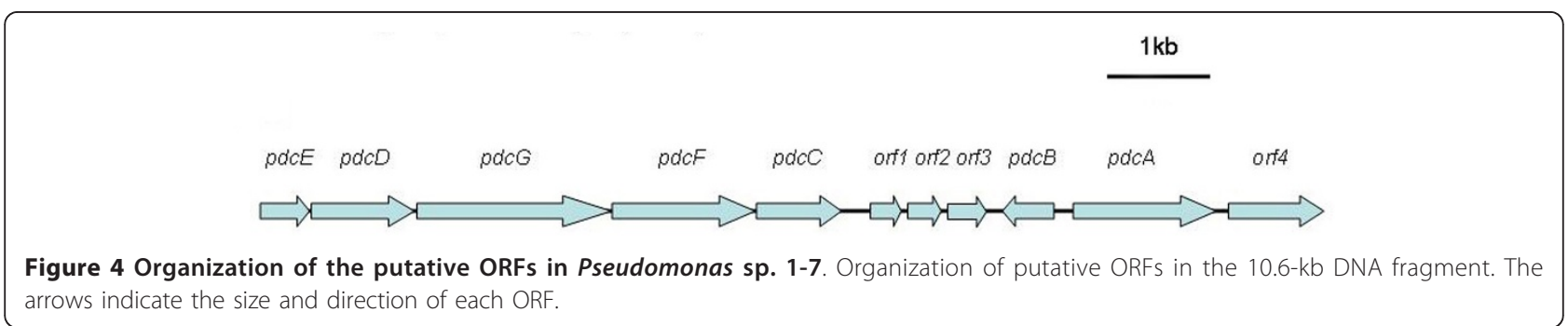




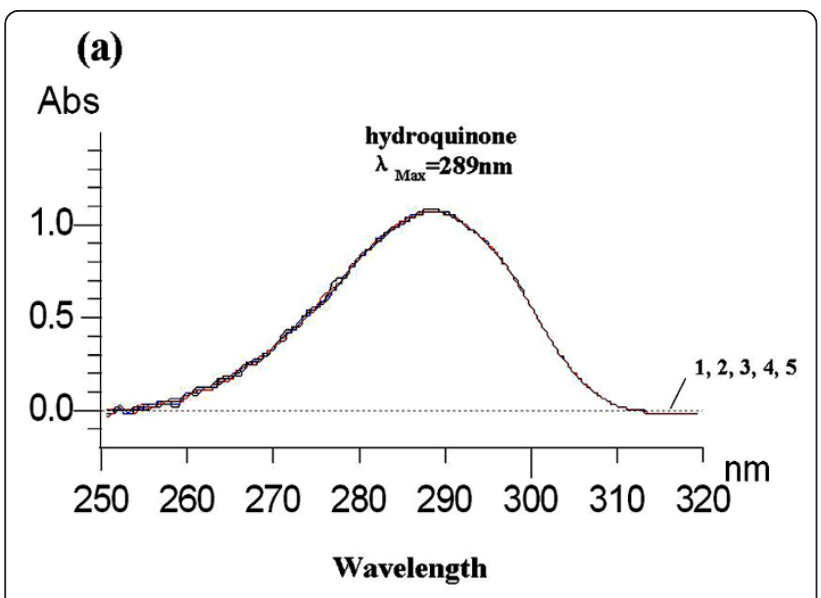

(b)

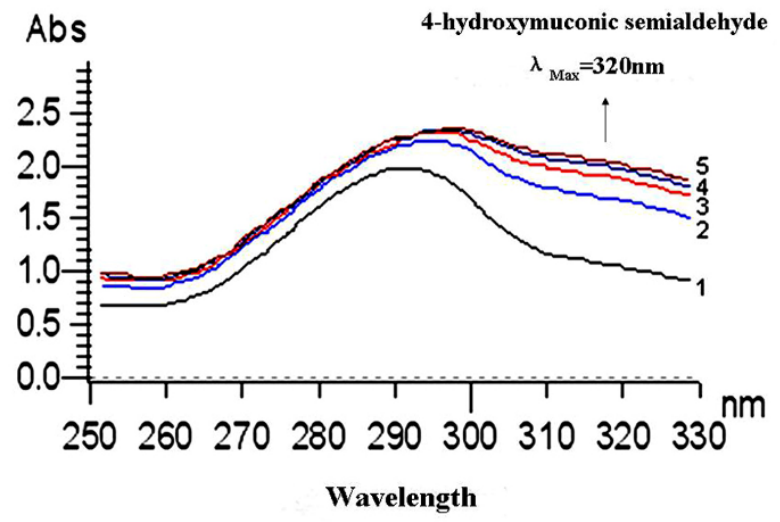

Figure 6 Enzyme activity assay of PdcDE. (a) Absorbance readings from $250 \mathrm{~nm}$ to $320 \mathrm{~nm}$ in the absence of $\mathrm{His}_{6}-\mathrm{PdcDE}_{\text {; }}$ (b) Spectral changes during rapid oxidation of $\mathrm{HQ}$ by purified $\mathrm{His}_{6}-$ PdcDE. The spectra were recorded a total of five times over a five minute period (marked 1-5). The arrows indicate the direction of spectral changes.

\section{Cloning of genes involved in PNP degradation}

Two positive clones (4-2 M and 4-8 G) were obtained by PCR-based screening of the genomic library of strain $1-7$, and a $10.6 \mathrm{~kb}$ fragment in 4-2 $\mathrm{M}$ containing 11 complete ORFs ( $p d c A B C D E F G$, orf1, orf2, orf3, orf4) was cloned. Their annotations were determined from BLAST analysis, and the ORF organization is shown in Figure 4. Genes $p d c A B C D E F G$ showed a high similarity with the reported PNP degradation cluster ( $p n p A B C D E F G)$ from Pseudomonas sp. strain WBC-3 [3], and the proteins PdcABCDEFG had no potential signal peptides as determined by SignalP 3.0.

\section{Expression and purification of PdcF, PdcG and PdcDE}

To characterize the enzymes involved in PNP degradation, four genes ( $p d c D E F G$ ) were expressed in $E$. coli BL21 (DE3). After purification by $\mathrm{Ni}^{2+}-\mathrm{NTA}$ affinity chromatography, the proteins $\mathrm{His}_{6}-\mathrm{PdcF}, \mathrm{His}_{6}-\mathrm{PdcG}$, His ${ }_{6}$-PdcD and His ${ }_{6}$-PdcE had been purified to apparent homogeneity by SDS-PAGE analysis. Their molecular masses were $37 \mathrm{kDa}, 52 \mathrm{kDa}, 38 \mathrm{kDa}$ and $18 \mathrm{kDa}$, respectively (Figure 5 ), being consistent with the calculated molecular masses of these proteins.

\section{Enzymatic assays of HQ 1,2-dioxygenase activity}

HQ 1,2-dioxygenase, being the third enzyme of the HQ pathway, catalyzes the ring cleavage reaction of HQ to 4-HS [21]. Two genes ( $p d c D$ and $p d c E$ ) were cloned into the expression vectors pET-30a and pET-2230, respectively, and $\mathrm{PdcD}$ and $\mathrm{PdcE}$ were co-expressed in E. coli BL21 (DE3) to allow endogenous assembly of the active HQ 1,2-dioxygenase. Spectrophotometric analysis of HQ 1,2-dioxygenase ( $\mathrm{His}_{6}$-PdcDE) activity showed a spectral change from $290 \mathrm{~nm}$ to $320 \mathrm{~nm}$ during the oxidation of $\mathrm{HQ}$ by $\mathrm{His}_{6}$-PdcDE (Figure $6 \mathrm{~b}$ ), there being no spectral changes in the negative controls (Figure 6a). These results indicated that $\mathrm{His}_{6}-\mathrm{PdcDE}$ catalyzed the ring cleavage reaction of $\mathrm{HQ}$ to 4-HS.

$\mathrm{His}_{6}$-PdcDE was active over a temperature range of $20-70^{\circ} \mathrm{C}$, with an optimal activity at $40^{\circ} \mathrm{C}$, and from $\mathrm{pH}$ 3.0-10.0 with an optimum activity at $\mathrm{pH} 6.0$ (Table 2, Additional file 1: Figure S3a, S3c). Further, the purified enzyme retained $35 \%$ activity after $20 \mathrm{~min}$ at $60^{\circ} \mathrm{C}, 20 \%$ activity after $30 \mathrm{~min}$ at $\mathrm{pH} 3.0$ and $60 \%$ activity after 30 min at $\mathrm{pH} 10.0$ (Additional file 1: Figure S3b, S3d). The influence of different metal ions, EDTA and SDS on enzyme activity is shown in Table 3.

\section{Enzymatic assays of 4-HS dehydrogenase activity}

The catalysis of 4-HS to MA by 4-HS dehydrogenase ( His $_{6}$-PdcG) was determined by monitoring the spectral changes at $320 \mathrm{~nm}$. During this enzyme assay, the

Table 2 Biochemical properties of the three enzymes

\begin{tabular}{|c|c|c|c|c|c|c|c|c|}
\hline Enzyme & $\begin{array}{l}\text { Temperature range } \\
\left({ }^{\circ} \mathrm{C}\right)\end{array}$ & $\begin{array}{c}\text { Optimal } \\
\text { temperature }\end{array}$ & $\begin{array}{c}\text { Thermal } \\
\text { Stability }^{(1)}\end{array}$ & $\underset{\text { range }}{\mathrm{pH}}$ & $\begin{array}{c}\text { Optimal } \\
\mathrm{pH}\end{array}$ & $\begin{array}{c}\text { Acid } \\
\text { stability }\end{array}$ & $\begin{array}{c}\text { Alkali }^{\text {Stability }} \\
\text { Stabili }^{(3)}\end{array}$ & $\begin{array}{l}\text { Specific } \\
\text { activity }\end{array}$ \\
\hline PdcDE & $20-70$ & $40^{\circ} \mathrm{C}$ & $35 \%$ & $3.0-10.0$ & 6.0 & $20 \%$ & $60 \%$ & $\mathrm{ND}^{(4)}$ \\
\hline PdcG & $20-70$ & $50^{\circ} \mathrm{C}$ & $65 \%$ & $5.0-10.0$ & 8.0 & $18 \%$ & $75 \%$ & $0.44 \mathrm{U} / \mathrm{mg}$ \\
\hline PdcF & $20-70$ & $40^{\circ} \mathrm{C}$ & $10 \%$ & $5.0-9.0$ & 7.0 & $20 \%$ & $58 \%$ & $446.97 \mathrm{U} / \mathrm{mg}$ \\
\hline
\end{tabular}

(1) Relative activity of purified protein when it was treated in $60^{\circ} \mathrm{C}$ for $20 \mathrm{~min}$;

(2) Relative activity of purified protein when it was treated in $\mathrm{pH} 3.0$ for $30 \mathrm{~min}$;

(3) Relative activity of purified protein when it was treated in $\mathrm{pH} 10.0$ for 30 min;

(4) Not detectedEach value represents the mean of at least three independent replicates. 
absorbance at $320 \mathrm{~nm}$ became progressively lower after purified $\mathrm{His}_{6}$-PdcG had been added to the reaction mixture in the presence of $\mathrm{NAD}^{+}$(Figure $7 \mathrm{~b}$ ). There was no disappearance of 4-HS in the negative controls (Figure 7a). His $_{6}$-PdcG thus catalyzed the oxidation of 4-HS to MA, confirming that PdcG was the enzyme downstream of PdcDE in the PNP degradation pathway in strain 1-7.

The specific activity of PdcG was calculated to be 0.44 $\mathrm{Umg}^{-1}$ (Table 2). PdcG was active over a temperature range of $20-70^{\circ} \mathrm{C}$ with an optimal activity at $50^{\circ} \mathrm{C}$, and over a $\mathrm{pH}$ range of 5.0-10.0 with an optimum activity at pH 8.0 (Additional file 1: Figure S4a, S4c). Further, the purified enzyme retained $65 \%$ activity after $20 \mathrm{~min}$ at $60^{\circ} \mathrm{C}, 18 \%$ activity after $30 \mathrm{~min}$ at $\mathrm{pH} \mathrm{3.0,} \mathrm{and} 75 \%$ activity after $30 \mathrm{~min}$ at $\mathrm{pH} 10.0$ (Additional file 1: Figure S4b, S4d). The influence of different metal ions, EDTA and SDS is shown in Table 3.

\section{Co-action of PdcDE and PdcG}

Because PdcG was able to metabolize the product of PdcDE, the activities of both $\mathrm{His}_{6}-\mathrm{PdcDE}$ and $\mathrm{His}_{6}-$ PdcG were assayed in one reaction mixture with HQ as the substrate. This was done spectrophotometrically by following the change of absorbance at $320 \mathrm{~nm}$. At the beginning of the reaction, the absorbance at $320 \mathrm{~nm}$ rose continuously (Figure $7 \mathrm{c}$ ), while no rising curve was observed in the negative control (data not shown). This indicated that 4-HS was generated in the reaction mixture containing both enzymes. After about 180 seconds, the absorbance plateaued, suggesting that the generation of 4-HS had reached a limit. $\mathrm{NAD}^{+}$(the cofactor of PdcG) was then added to the reaction mixture to a final concentration of $0.05 \mathrm{mM}$ to activate $\mathrm{His}_{6}$-PdcG. Upon addition of $\mathrm{NAD}^{+}$, the absorbance at $320 \mathrm{~nm}$ immediately decreased rapidly, and then leveled off. However, no such results were observed when $\mathrm{His}_{6}-\mathrm{PdcG}$ was omitted from the reaction or when $\mathrm{His}_{6}$-PdcDE was incubated with a crude cell extract of the non-induced BL21 strain that harbored $p d c F$ instead of $\mathrm{His}_{6}$-PdcG (data not shown). This confirmed that 4-HS was the product of $\mathrm{His}_{6}-\mathrm{PdcDE}$ acting on $\mathrm{HQ}$, and that 4-HS was the substrate of the enzyme $\mathrm{His}_{6}$-PdcG.

\section{Enzymatic assays of MA reductase activity}

MA reductase is the common enzyme of the two PNP degradation pathways and uses $\mathrm{NADH}$ as a cofactor [22]. In the MA reductase $\left(\mathrm{His}_{6}-\mathrm{PdcF}\right)$ assay, the decrease in absorption at $340 \mathrm{~nm}$ was used to monitor the conversion of $\mathrm{NADH}$ to $\mathrm{NAD}^{+}(\varepsilon 340 \mathrm{NADH}=6.3$ mM-1 cm-1), which conversion reflects the activity of $\mathrm{His}_{6}-\mathrm{PdcF}$. When purified $\mathrm{His}_{6}$-PdcF was added to the assay mixture, there was significant oxidation of $\mathrm{NADH}$ (Figure 8a). However, no oxidation of NADH was observed when $\mathrm{His}_{6}-\mathrm{PdcF}$ was omitted from the reaction (Figure $8 \mathrm{~b}$ ). Thus, PdcF reduced MA to $\beta$-ketoadipate with NADH as a cofactor.

$\mathrm{His}_{6}$-PdcF was active over a temperature range of 20$70^{\circ} \mathrm{C}$ with an optimal activity at $40^{\circ} \mathrm{C}$, and over a $\mathrm{pH}$ range of 5.0-9.0 with an optimum activity at $\mathrm{pH} 7.0$ (Table 2, Additional file 1: Figure S5a, S5c). Its specific activity was calculated to be $446.97 \mathrm{Umg}^{-1}$. Further, the purified enzyme retained $10 \%$ activity after $20 \mathrm{~min}$ at $60^{\circ} \mathrm{C}, 20 \%$ activity after $30 \mathrm{~min}$ at $\mathrm{pH} 3.0$, and $58 \%$ activity after $30 \mathrm{~min}$ at $\mathrm{pH} 10.0$ (Additional file 1: Figure S5b, S5d). The influence of different metal ions, EDTA and SDS is shown in Table 3.

Table 3 Effect of various metal ions and chemical agent on the activity of the three enzymes

\begin{tabular}{|c|c|c|c|}
\hline \multirow[t]{2}{*}{ Metal ion or chemical agent $(5 \mathrm{mM})$} & \multicolumn{3}{|c|}{ Relative activity (\%) } \\
\hline & PdcDE & PdcG & PdcF \\
\hline No addition & 100 & 100 & 100 \\
\hline $\mathrm{K}^{+}(\mathrm{KCl})$ & $113.04 \pm 10.80$ & $95.79 \pm 16.49$ & $129.00 \pm 27.32$ \\
\hline $\mathrm{Na}^{+}(\mathrm{NaCl})$ & $113.42 \pm 2.27$ & $88.22 \pm 17.76$ & $123.91 \pm 25.82$ \\
\hline $\mathrm{Ba}^{2+}\left(\mathrm{BaCl}_{2}\right)$ & $99.19 \pm 6.29$ & $123.34 \pm 7.79$ & $129.02 \pm 6.46$ \\
\hline $\mathrm{Mg}^{2+}\left(\mathrm{MgCl}_{2}\right)$ & $95.41 \pm 5.96$ & $138.06 \pm 8.46$ & $129.79 \pm 18.11$ \\
\hline $\mathrm{Zn}^{2+}\left(\mathrm{ZnCl}_{2}\right)$ & $87.44 \pm 8.68$ & $145.95 \pm 5.13$ & $21.44 \pm 3.71$ \\
\hline $\mathrm{Cu}^{2+}\left(\mathrm{CuCl}_{2}\right)$ & $22.46 \pm 6.83$ & $110.18 \pm 11.17$ & $59.23 \pm 12.57$ \\
\hline $\mathrm{Ni}^{2+}\left(\mathrm{NiCl}_{2}\right)$ & $111.05 \pm 2.61$ & $183.93 \pm 30.68$ & $35.25 \pm 16.67$ \\
\hline $\mathrm{Co}^{2+}\left(\mathrm{CoCl}_{2}\right)$ & $104.15 \pm 6.79$ & $147.08 \pm 17.51$ & $79.14 \pm 13.21$ \\
\hline $\mathrm{Mn}^{2+}\left(\mathrm{MnCl}_{2}\right)$ & $77.45 \pm 2.93$ & $186.12 \pm 9.99$ & $136.59 \pm 3.65$ \\
\hline $\mathrm{Cd}^{2}+\left(\mathrm{CdSO}_{4}\right)$ & $63.24 \pm 3.61$ & $58.93 \pm 3.88$ & $39.52 \pm 7.01$ \\
\hline $\mathrm{Fe}^{2+}\left(\mathrm{FeCl}_{2}\right)$ & $82.13 \pm 13.46$ & $39.47 \pm 9.49$ & $118.90 \pm 21.53$ \\
\hline $\mathrm{Fe}^{3+}\left(\mathrm{FeCl}_{3}\right)$ & $78.33 \pm 10.74$ & $187.37 \pm 15.37$ & $134.89 \pm 28.19$ \\
\hline EDTA & $62.44 \pm 3.90$ & $83.17 \pm 8.32$ & $112.93 \pm 40.43$ \\
\hline SDS & $97.47 \pm 1.65$ & $81.58 \pm 24.05$ & $136.59 \pm 3.66$ \\
\hline
\end{tabular}




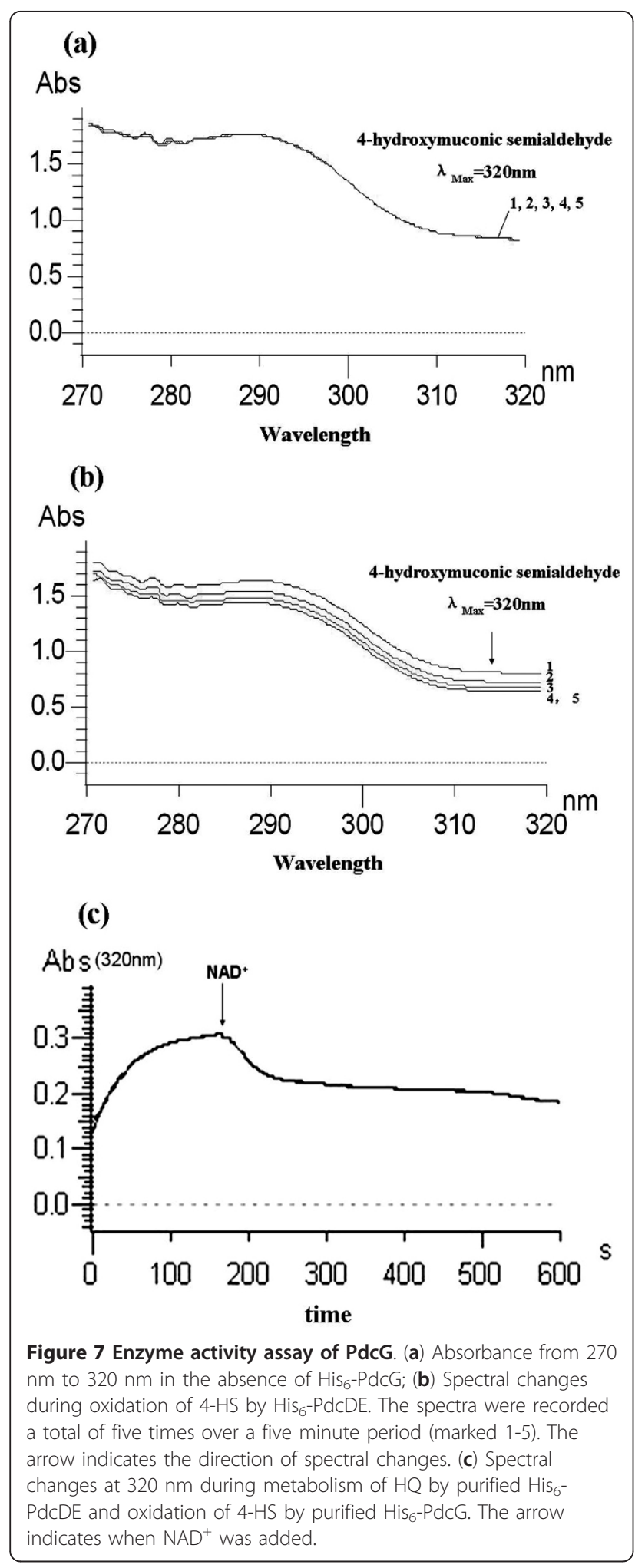

\section{Discussion}

Pseudomonas sp.1-7, a gram-negative bacterium isolated from MP-polluted activated sludge, was able to catabolize both MP and its initial hydrolysis product PNP. (a)

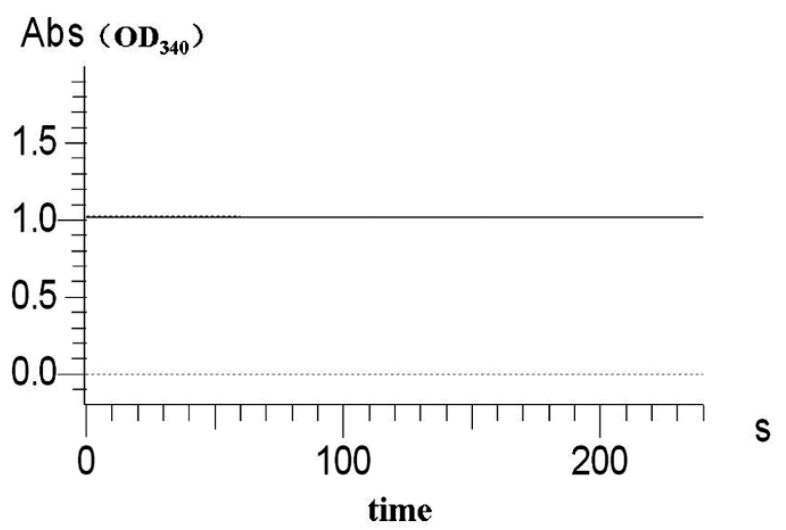

(b)

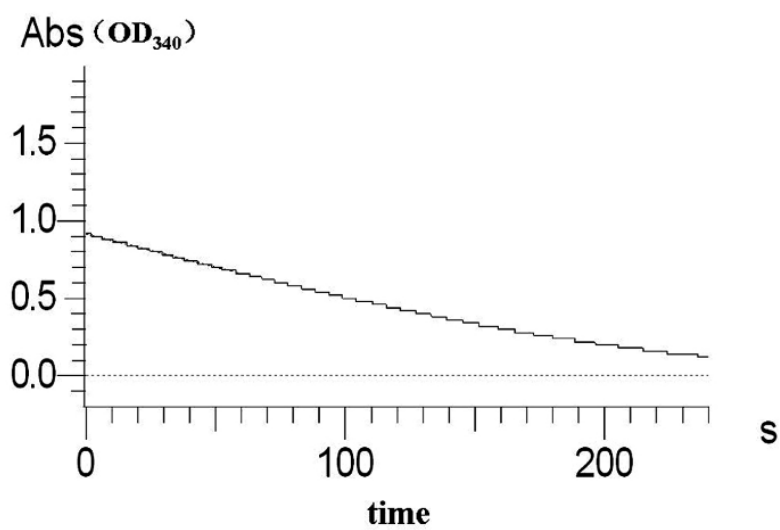

Figure 8 Enzyme activity assay of PdcF. (a) Absorbance at 340 $\mathrm{nm}$ in the absence of $\mathrm{His}_{6}-\mathrm{PdcF}$; (b) Absorbance at $340 \mathrm{~nm}$ during oxidation of $\mathrm{NADH}$ by $\mathrm{His}_{6}-\mathrm{PdcF}$.

Using HPLC and LC-MS, we demonstrated that strain 1-7 degraded PNP through two different pathways, the HQ pathway and the BT pathway. A gene cluster $p d c A B C D E F G$ involved in PNP degradation was identified in Pseudomonas sp.1-7. Genes pdcABDEFG were involved in the HQ pathway, and genes $p d c C G$ were involved in the BT pathway. The BT pathway also needs a two-component PNP monooxygenase (Figure 1) to catalyze PNP to 4-NC and BT [5]; however, we did not find the relevant PNP monooxygenase in the gene cluster. We speculate that the monooxygenase PdcA in the HQ pathway may have two functions, catalyzing PNP to both BQ and 4-NC. This is supported by recent reports indicating that the HQ pathway monooxygenase has the ability to catalyze 4-NC to BT, normally thought to be the work of the BT pathway monooxygenase [11]. This suggests that the HQ pathway monooxygenase could be substituted for the BT pathway monooxygenase in the process of PNP degradation. In future studies, we will identify whether there are BT pathway-specific PNP 
monooxygenase genes, or whether the HQ pathway monooxygenase is a bi-functional enzyme in strain 1-7.

We also identified three enzymes (PdcDE, PdcF and PdcG) in the HQ pathway. PdcDE was a two-component dioxygenase and catalyzed HQ to 4-HS. PdcG was a 4-HS dehydrogenase that catalyzed 4-HS to MA. PdcF was a MA reductase which transformed MA to $\beta$-ketoadipate. All three enzymes performed optimally at temperatures of $40-50^{\circ} \mathrm{C}$, and at nearly neutral $\mathrm{pH}(\mathrm{pH} 6.0-$ 8.0). Regarding stability, only PdcG has a better thermal stability at $60^{\circ} \mathrm{C}(65 \%$ retention of activity after $20 \mathrm{~min}$ exposure) than the other two enzymes (10\% to $35 \%$ retention). All of the enzymes had better alkali stability at $\mathrm{pH} 10.0$ (58\% to $75 \%$ retention of activity after 30 min exposure) than acid stability at pH 3.0 (18\% to $20 \%$ retention).

The HQ dioxygenase gene has been identified in other bacteria [12,21], but little is known about the properties of its corresponding enzyme. Our research on the enzyme (PdcDE) will hopefully contribute to our understanding. Of the two, the MA reductase PdcF was the more active enzyme, with a specific activity of 446.97 $\mathrm{Umg}^{-1}$ as opposed to $13.33 \mathrm{Umg}^{-1}$. It is also the first time that a 4-HS dehydrogenase (PdcG) has been extensively characterized.

\section{Conclusions}

Pseudomonas sp.1-7, with the capability of degrading MP and PNP, was isolated from MP-polluted activated sludge. The bacterium utilized two pathways for PNP degradation, the HQ pathway and the BT pathway. Three enzymes (PdcDE, PdcF and PdcG) in the HQ pathway were expressed, purified, and characterized. Our research will pave the way for a better understanding of the PNP degradation pathway in gram-negative bacteria.

\section{Additional material}

Additional file 1: This section mainly involves the methods of the enzyme assays and some figure data about the enzyme charactication. Additionally, this file also includes a table about the primers used in this study, a figure reflects the concentration changes of the substrate and of the two intermediates in the course of the PNP degradation and another figure about the specific absorbs curved line which reflects the detected peak by HPLC $[13,21,22]$.

\begin{abstract}
Abbreviations
4-HS: 4-hydroxymuconic semialdehyde; 4-NC: 4-Nitrocatechol; BT: Hydroxyquinol; BQ: p-benzoquinone; HQ: Hydroquinone; MP: Methyl parathion; MA: Maleylacetate; PNP: para-Nitrophenol.
\end{abstract}

\section{Acknowledgements}

The work was supported by the National Natural Science Foundation of China (Grant No.31170036).

\section{Authors' contributions}

NFW designed the experiment and revised the manuscript. SYZ carried out most of molecular genetic studies and drafted the manuscript. WS and LX participated part of experiments. XYC and JT conceived of the study, participated in its design and coordination and helped to draft the manuscript. YLF and XMZ revised the manuscript and give many important suggestions. All authors read and approved the final manuscript.

Received: 18 July 2011 Accepted: 2 March 2012

Published: 2 March 2012

\section{References}

1. Bondarenko S, Gan J, Haver DL, Kabashima JN: Persistence of selected organophosphate and carbamate insecticides in waters from a coastal watershed. Environ Toxicol Chem 2004, 23(11):2649-2654.

2. Spain JC, Gibson DT: Pathway for Biodegradation of $\mathrm{p}$-Nitrophenol in a Moraxella sp. Appl Environ Microbiol 1991, 57(3):812-819.

3. Zhang JJ, Liu H, Xiao Y, Zhang XE, Zhou NY: Identification and characterization of catabolic para-Nitrophenol 4-Monooxygenase and para-Benzoquinone reductase from Pseudomonas sp. Strain WBC-3. J Bacteriol 2009, 191(8):2703-2710.

4. Perry LL, Zylstra GJ: Cloning of a gene cluster involved in the catabolism of p- Nitrophenol by Arthrobacter sp. Strain JS443 and characterization of the p-nitrophenol monooxygenase. J Bacteriol 2007, 189(21):7563-7572.

5. Kitagawa W, Kimura N, Kamagata Y: A Novel p-Nitrophenol Degradation Gene Cluster from a Gram-Positive Bacterium, Rhodococcus opacus SAO101. J Bacteriol 2004, 186(15):4894-4902.

6. Jain RK, Dreisbach JH, Spain JC: Biodegradation of p-nitrophenol via 1,2,4benzenetriol by an Arthrobacter sp. Appl Environ Microbiol 1994, 60(8):3030-3032

7. Kadiyala V, Spain JC: A two-component monooxygenase catalyzes both the hydroxylation of p-nitrophenol and the oxidative release of nitrite from 4-nitrocatechol in Bacillus sphaericus JS905. Appl Environ Microbiol 1998, 64(7):2479-2484.

8. Chauhan A, Pandey G, Sharma NK, Paul D, Pandey J, Jain RK: p-Nitrophenol degradation via 4-nitrocatechol in Burkholderia sp. SJ98 and cloning of some of the lower pathway genes. Environ Sci Technol 2010, 44(9):3435-3441.

9. Yamamoto K, Nishimura M, Kato D-i, Takeo M, Negoro S: Identification and characterization of another 4-nitrophenol degradation gene cluster, nps, in Rhodococcus sp. strain PN1. J Biosci Bioeng 2011.

10. Takeo M, Murakami M, Niihara S, Yamamoto K, Nishimura M, Kato Di, Negoro S: Mechanism of 4-Nitrophenol oxidation in Rhodococcus sp. Strain PN1: characterization of the two-component 4-Nitrophenol hydroxylase and regulation of its expression. J Bacteriol 2008, 190(22):7367-7374.

11. Wei M, Zhang J-J, Liu H, Zhou N-Y: para-Nitrophenol 4-monooxygenase and hydroxyquinol 1,2-dioxygenase catalyze sequential transformation of 4-nitrocatechol in Pseudomonas sp. strain WBC-3. Biodegradation 2010, 21(6):915-921

12. Shen W, Liu W, Zhang J, Tao J, Deng H, Cao H, Cui Z: Cloning and characterization of a gene cluster involved in the catabolism of $p$ nitrophenol from Pseudomonas putida DLL-E4. Bioresour Technol 2010, 101(19):7516-7522.

13. Moonen $\mathrm{MH}$, Kamerbeek NM, Westphal AH, Boeren SA, Janssen DB, Fraaije MW, van Berkel WJH: Elucidation of the 4-Hydroxyacetophenone Catabolic Pathway in Pseudomonas fluorescens ACB. J Bacteriol 2008, 190(15):5190-5198

14. Kennedy C, Gamal R, Humphrey R, Ramos J, Brigle K, Dean D: The nifH, nifM and nifN genes of Azotobacter vinelandii: characterisation by Tn5 mutagenesis and isolation from pLAFR1 gene banks. Mol Gen Genet MGG 1986, 205(2):318-325.

15. Sambrook J, Fritsch EF, Maniatis T: Molecular cloning: a laboratory manual. 2 edition. N.Y.: Cold Spring Harbor Laboratory Press; 1989.

16. Li Xu XC, Jian Tian, Ningfeng WU: Gene cloning and properties of a methyl parathion hydrolase from Pseudomonas sp.1-7. J Pestic Sci (in Chinese) 2011, 13(2):162-168.

17. Samanta S: Chemotaxis of a Ralstonia sp. SJ98 toward different nitroaromatic compounds and their degradation. Biochem Biophys Res Commun 2000, 269(1):117-123. 
18. Wheeler DL, Church DM, Federhen S, Lash AE, Madden TL, Pontius JU, Schuler GD, Schriml LM, Sequeira E, Tatusova TA, et al: Database resources of the national center for biotechnology. Nucleic Acids Res 2003, 31(1):28-33.

19. Ye J, McGinnis S, Madden TL: BLAST: improvements for better sequence analysis. Nucleic Acids Res 2006, , 34 Web Server: W6-9.

20. Zhou NY, Fuenmayor SL, Williams PA: nag genes of Ralstonia (formerly Pseudomonas) sp. strain U2 encoding enzymes for gentisate catabolism. J Bacteriol 2001, 183(2):700-708.

21. Moonen MJH, Synowsky SA, van den Berg WAM, Westphal AH, Heck AJR, van den Heuvel RHH, Fraaije MW, van Berkel WJH: Hydroquinone

Dioxygenase from Pseudomonas fluorescens ACB: a novel member of the family of Nonheme-Iron(II)-dependent dioxygenases. J Bacteriol 2008, 190(15):5199-5209.

22. Dayna L, Daubaras KSt, Chakrabarty AM: Purification of hydroxyquinol 1,2dioxygenase and maleylacetate reductase: the lower pathway of 2,4,5trichlorophenoxyacetic acid metabolism by Burkholderia cepacia AC1100. Appl Environ Microbiol 1996, 62(11):4276-4279.

doi:10.1186/1471-2180-12-27

Cite this article as: Zhang et al: Identification of the para-nitrophenol catabolic pathway, and characterization of three enzymes involved in the hydroquinone pathway, in pseudomonas sp. 1-7. BMC Microbiology 2012 12:27.

\section{Submit your next manuscript to BioMed Central} and take full advantage of:

- Convenient online submission

- Thorough peer review

- No space constraints or color figure charges

- Immediate publication on acceptance

- Inclusion in PubMed, CAS, Scopus and Google Scholar

- Research which is freely available for redistribution

Submit your manuscript at www.biomedcentral.com/submit 